\title{
CONTRIBUTION OF ARCHITECT DAINA DANNEBERGA TO THE ARCHITECTURE IN THE SECOND HALF OF THE 20TH CENTURY
}

\section{ILZE GUDRO*, JĀNIS KRASTIN̦Š}

Riga Technical University

\begin{abstract}
Summary. The article reflects the contribution of the renowned Latvian architect Daina Danneberga to Latvian architecture, as well as the significant events and growth of her life. While living and working in Soviet times, the architect has designed both residential and public buildings, which are still in use and whose cultural and historical significance has surely increased over the time. The most recognizable object designed by the architect is the Student Campus of Riga Polytechnic Institute (RPI), now Riga Technical University (RTU), on the Kipsala Island. It was designed by D. Danneberga from 1969 to 1986. The architect has also developed projects for several other educational institutions as well as public and residential buildings, both in Latvia and abroad.
\end{abstract}

Keywords: Daina Danneberga, RPI / RTU Kīpsala Campus, architecture of the second half of the 20th century.

\section{The Family of Daina Danneberga}

D. Danneberga was born on 25 March 1929 in Riga city, in the family of Leontine Kimele (born Krom) and Konstantins Kimels (also Kimmels, Kimmelis, Kimmelis). Her parents were born in Valka county: her mother in Alsviki parish and father in Anna parish. In 1932, Daina's sister Guna was born.

D. Danneberga's mother and father were tailors. During World War II, both parents continued their work in the family sewing company «K. Kimelis» founded by K. Kimels' father. In Soviet times, the company was liquidated and the father began working as the Chief-cutter in sewing company «Sadarbība» («Cooperation»), but the mother became

\footnotetext{
* Corresponding author.

E-mail: ilze.gudro@rtu.lv
} 
a housewife. For health reasons, she could no longer continue working. Daina also wanted to become a modeller, but it was not possible to acquire such a profession in the Soviet Union.

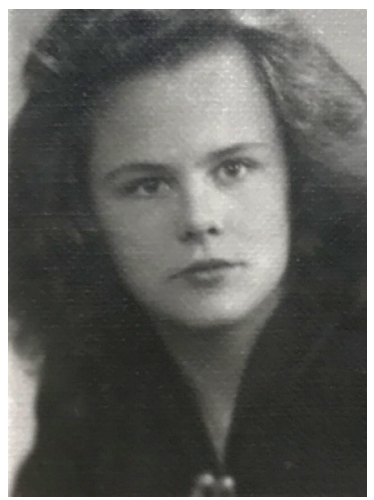

Figure 1. D. Danneberga (1952) [1].

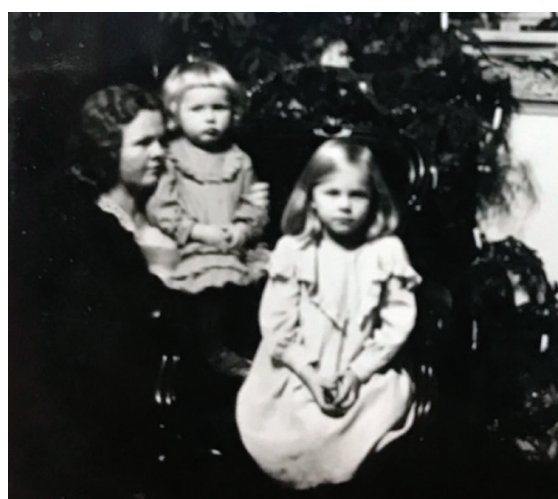

Figure 2. From the left - Daina's mother Leontine, sister Guna and Daina in the apartment in Riga city (around 1934) [2].

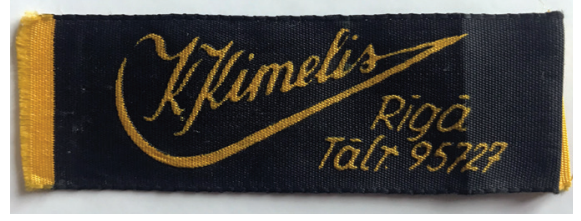

Figure 3. The logo of sewing company «K. Kimelis» (1940) [3].

In one of the balls during school years, Daina met her future husband, Tãlivaldis Dannebergs (1926-1958). The small wedding took place in 1949 of immediate family. Unfortunately, Daina's first husband became ill with tuberculosis and died very young in 1958 . He was the son of the Cavalier of the Order of Three Stars General Artūrs Dannebergs (1891-1941). D. Danneberga got married for the second time in 1960 with Ilgvars Veigners. Two daughters were born in this marriage.

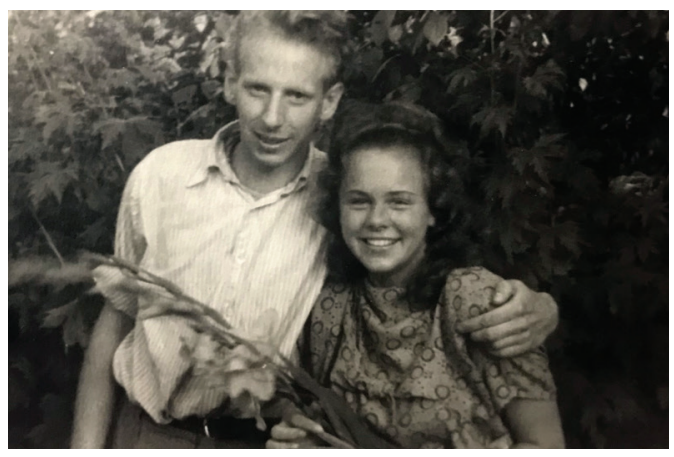

Figure 4. Both Dannebergs week after the wedding day in Melluži (residential area and neighbourhood of the Jürmala city) (1949) [4]. 


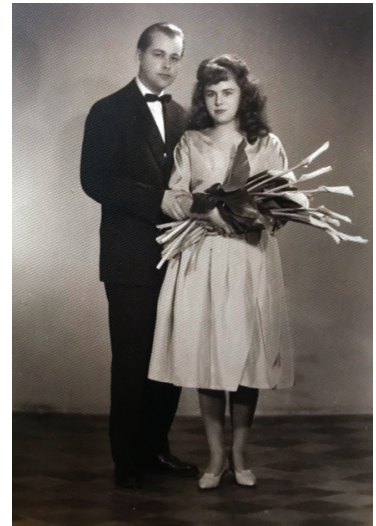

Figure 5. I. Veigners and D. Danneberga on their wedding day (1960) [5].

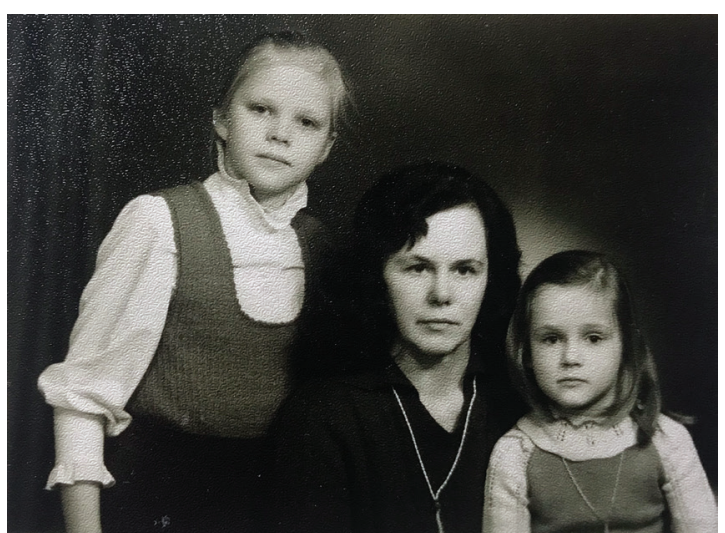

Figure 6. D. Danneberga with daughters Helga and Nora (around 1980) [6].

\section{Education of Daina Danneberga}

D. Danneberga began her schooling at Riga Elementary School No. 2, which she graduated in 1944. Then she entered Riga Secondary School No. 2, which she graduated in 1949 [7].

During her studies, Daina sang in the school choir and was an editor of the classroom wall paper. Director of the secondary school described Daina as a gifted pupil with sharp and clear mind, lively in social work, who read a lot and actively participated in the debate, as well as attended lectures at the Pioneer Palace of the Latvian Soviet Socialist Republic (LSSR), theatres, cinemas and opera [8].

D. Danneberga's career was related with her first husband Tälivaldis, as he inspired her to become an architect. Encouraged by her husband, D. Danneberga enrolled in the Faculty of Architecture of the State University of Latvia (SUL) in 1949. They married during their study years. This is also evidenced by D. Danneberga's request to the Personnel Department of SUL to change her surname in her personal file to her married name.

Figure 7. Reference to the Personnel Department of SUL regarding the change of D. Danneberga's name, dated 19 October 1949 [9].

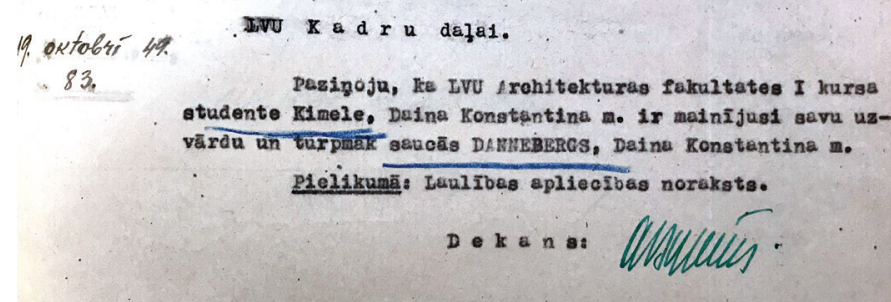


The study time at the university was associated with significant turbulences in defining guidelines for the architecture in the Union of Soviet Socialist Republics (USSR) and in the politicization of many professional issues. D. Danneberga and her first husband T. Dannebergs studied at the same university, but in different courses. They both had good grades [10]. In one of the minutes of the Exhibition Commission of the University, at the time when the discussion on the closure of the Faculty of Architecture occurred, it was noted that some of the students (including D. Danneberga's husband Tālivaldis) were hiding their works to make corrections; that they are disloyal to the system because as they are bourgeois nationalists. Tälivaldis was wrongly accused and punished - he was ordered to withdraw his documents from the university. On 1 March 1952, in solidarity for her husband, Daina submitted an application to the Management of SUL to dismiss her from the University due to family circumstances [11].

For some time (20.03.1952-27.03.1952), Daina made copies and drawings at the Design Institute «Латгипрогорстрой» («Latgiprogorstroj») [12]. The earned money was used for medicine to treat her husband. In 1952, both Dannebergs begun part-time studies at the Leningrad Construction Engineering Institute in Riga city. In the summer of 1954, both switched to full-time studies. Tãlivaldis was the 4th and Daina was the 3rd year student. Both wanted to graduate the institute at the same time, therefore Daina had already passed several exams at the part-time studies and continued intensive studies [13].

Daina studied with architect Professor Andrei Olj (Андрей Андреевич Оль; 1883-1958), who at the beginning of the 20th century had worked in Finland with architects Armas Eliel Lindgren (1874-1929) and Eliel Saarinen (1873-1950), cultivating good taste and culture of architectural details. The Professor had a significant influence on Daina's future understanding of modern architecture. The theme of D. Danneberga's diploma paper was «Experimental Residential Quarter in Leningrad» (1957).

On her return to Riga city, the young architect worked with her former study mates from SUL - Olggerts Krauklis, Modris Gelzis, Viktors Zilgalvis, Arvìds Celadoms, Irēna Rubauska, Reginna Jaunušāne, Alberts Kalmanis, Vasilijs Nikiforovs and others who graduated in 1955.

\section{Daina Danneberga's Professional Career}

Already when having practice during her studies Daina was involved in the design process of the «Riga» hotel. After returning from studies 
in Leningrad at the end of the 1950s, the architect and her husband Tálivaldis actively participated in several architectural design contests.

For the next five years, she held various positions at the Design Institute «Latgiprogorstroj» (later called «Pilsētprojekts» «City Project»)) - an Acting Technician, Technician, Chief Technician, Acting Architect, Architect, but from 1960 until 1986, she was the Chief Architect.

On 1 November 1986, she was recruited as a Master of Training at RPI with a salary of 120 rubles per month. On 16 January 1990, D. Danneberga was nominated a Master of Training in the Division of Capital Building of RPI, where she worked as a Specialist of the 1st Category from 24 April 1991. On 1 September 1993, upon her request, she interrupted employment relationship with RTU, however until 3 December 1999 - until retirement - she took various jobs at RTU, mainly related to management of RTU property.

The architect's creative work had a special upswing in the 1970s and 1980s, which was the time when her most significant works were created. Since 1960, she has been a member of the Latvian Association of Architects.

\section{Daina Danneberga's Most Notable Architectural Projects in Latvia and Kazakhstan}

In the 1930s, functionalism or modern movement flourished around the world, becoming a dominant style of the entire century. However, in the second half of the 1930s, as an alternative, neo-eclecticism based on the classical expression also developed. It spread after World War II under the name of «socialist realism» in the Soviet Union. It was called «Stalin's Empire» or «Stalin's Baroque». In 1955, this retrospective orientation in the form of a directive was interrupted by the decisions of the Council of Ministers of the Communist Party of the Soviet Union: «On Prevention of Excesses in Design and Construction» and «On Measures for Further Industrialization, Improvement of Quality and Reduction of Construction Costs». They changed the direction of the development of architecture to a more contemporary one, nevertheless the overall dictatorship of industrialization of construction drastically limited the creative diversity and individuality of architecture. However, even under these circumstances D. Danneberga was able to create buildings that are distinguished for a certain architecturally artistic quality.

The architect also managed to take part in trips to Polish People's Republic, the German Democratic Republic (1968), Czechoslovak Socialist Republic and Hungarian People's Republic (1971), thus widening the
Contribution of

Architect

Daina Danneberga to the Architecture in the Second Half of the 20th Century 
The Palace of Tselinograd Virgin Land Developers (in Russian: Дворец целинников (Dvorec Celinnikov)) in Tselinograd (in Russian: Целиноград), at present - Nur-Sultan, Kazakhstan. 1960-1963. Architects $O$. Kraulis, D. Danneberga and P. Fogels.

The origins of the building were the idea of building a panoramic cinema in Riga city, between Krišjāna Barona, Artilērijas, Têrbatas and Lielgabala iela (in 1970, the Riga Sports Palace was built there, which was demolished in 2008). The model of the project that had received the top rating was exhibited at the National Exhibition of Economic Achievements in Moscow, where it was noticed by the then USSR Dictator Nikita Khrushchev who instructed: «We need such a building in Tselinograd». It was a newly established main city in the pristine lands of Khrushchev. Now it is the capital of Kazakhstan - Nur-Sultan.

The building in Tselinograd was built under the guidance of Latvian architects, who carried out operational work, developed technical documentation and supervised the construction for two years. Five project organizations from Moscow, Leningrad and Riga cities also participated in the development of the project together with the Latvian State Urban Design Institute [20]. The hall and lobby furniture of the palace were made in the Riga Furniture Factory according to the drawings of the specialists of the Central Construction Office of the Paper and Wood Processing Industry Department of the National Council of Economy [21].

Figure 10. The plan of the Palace of Tselinograd Virgin Land Developers (1960).

Room designations:

1 - main entrance;

2 - cash desk in the lobby;

3 - lobby;

4 - cloakroom;

5 - foyer;

6 - cafe;

7 - toilets;

8 - the hall;

9 - stage;

10 - orchestra;

11 - actors' premises;

12 - technical premises;

13 - administration;

14 - terrace [22].

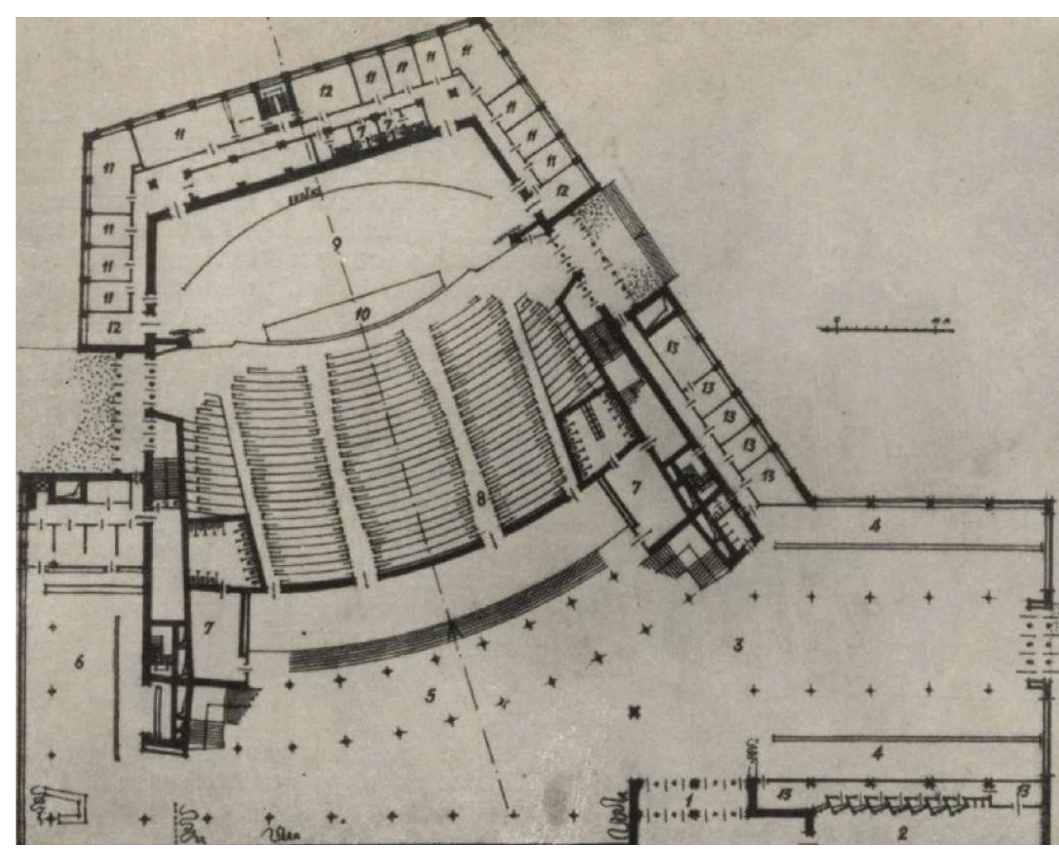


The building was located in the city park, at the end of the main street and immediately after its opening was given the name of «The Palace of Tselinograd Virgin Land Developers». The building was visible from a distance of several kilometres. The domineering part of the huge construction - the large hall for 2350 spectators, was rising above the lower front part of the building - the lobby and foyer. In the back, there are two-storeys with auxiliary rooms. The total cubic capacity of the building is $64000 \mathrm{~m}^{3}$, building area -0.54 hectares and the hall for spectators is 25 meters high. There are 10 movie projectors in the movie projection room. The screen was 13 meters high and 34 meters wide. $962 \mathrm{~m}^{2}$ of polished mirror glass was used for glazing exterior walls.

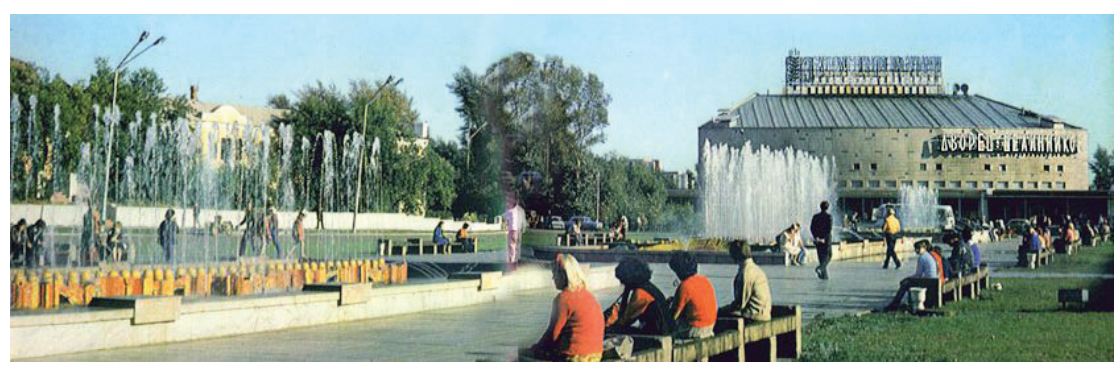

Figure 11. View to the main facade of the Palace of Tselinograd Virgin Land Developers (1963) [23].

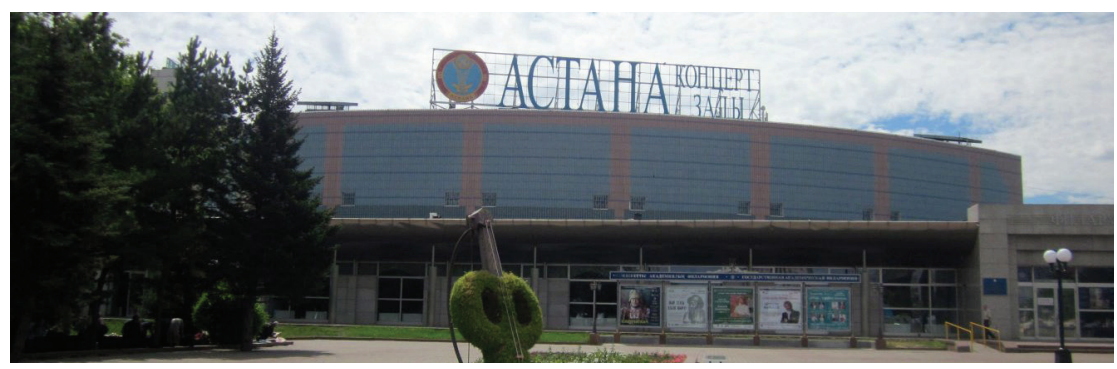

Figure 12. The main facade of the Palace of Tselinograd Virgin Land Developers (until March 2019 - Astana Concert Hall) (2017) [24].

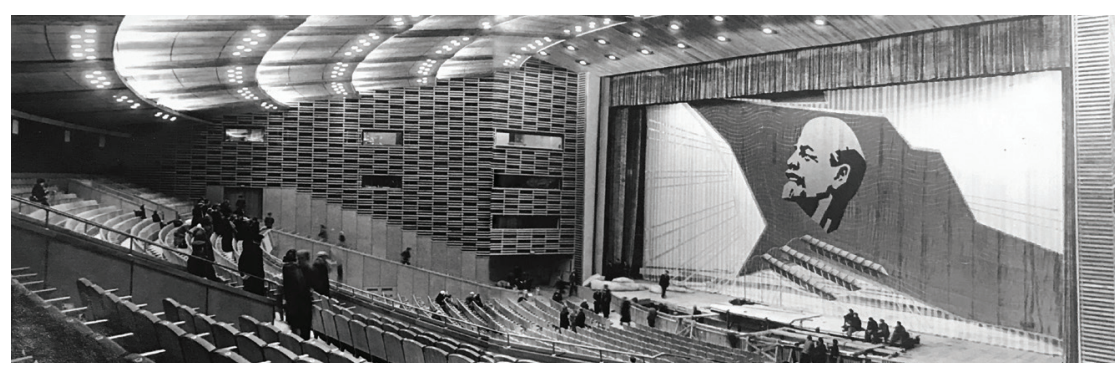

Figure 13. The hall of the Palace of Tselinograd Virgin Land Developers (1963) [25]. 


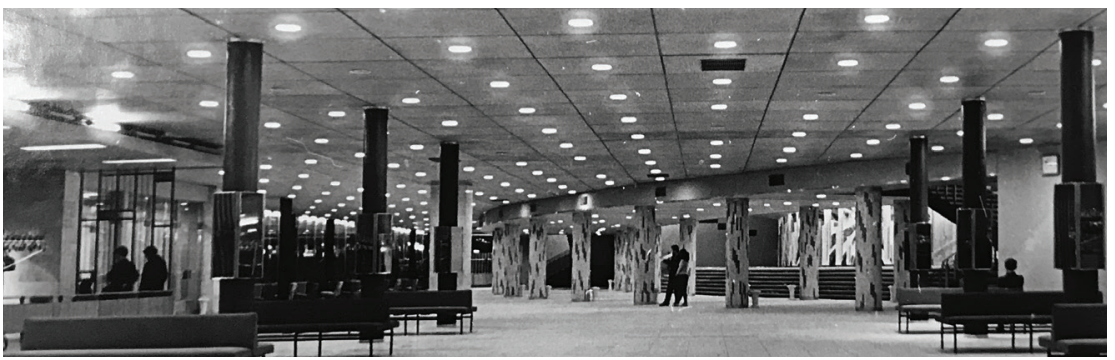

Figure 14. Foyer of the Palace of Tselinograd Virgin Land Developers (1963) [26].

At the beginning of 1963, D. Danneberga received the All-Union Medal «For the Development of Virgin Lands» for participation in the implementation of the project.

The House of the Union of Latvian Fishermen Kolkhozs at 13 Jauniela, Riga city. 1964-1967. Architect D. Danneberga. The eastern part of the Riga Dome Square was densely built until World War II. Buildings along Tirgonu iela were destroyed during the war and in the block of houses between Rozena and Jauniela there was a destroyed building at 13 Jauniela. The house built in the style of eclecticism at 11 Jauniela (1860; architect Friedrich Hess), where there was a popular cafe on the ground floor in the early 1970s, stood like a lonely tower in a prominent place. Then, in the empty plot of land at 13 Jauniela, to the project of architect D. Danneberga, the House of the Union of Latvian Fishermen Kolkhozs was built, filling the space between the building at 11 Jauniela and the building built in the 18th century at 15 Jauniela. This building organically integrates in the environment and at the same time reflects northern thoroughness [27]. The house was recognized as a successful example of contextual architecture immediately after its construction.

The architect was awarded the Honorary Diploma at the Creative Exhibition organized by the Architects' Union of the USSR [28].

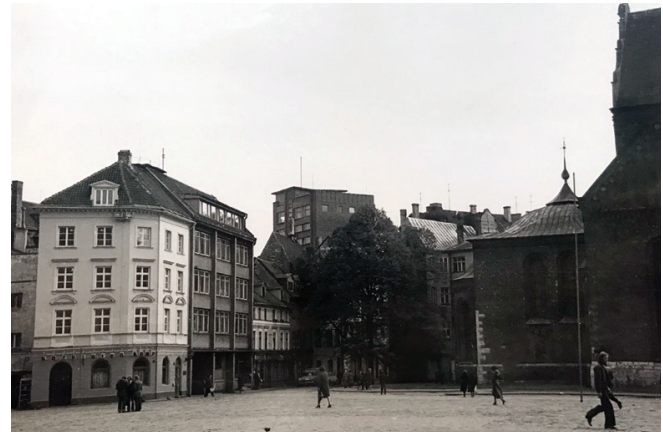

Figure 15. The House of the Union of Latvian Fishermen Kolkhozs at 13 Jauniela, Old Town (in the 1970s) [29].

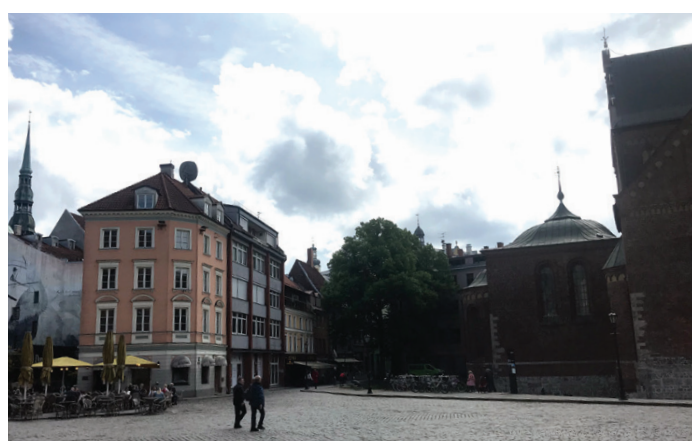

Figure 16. The House of the Union of Latvian Fishermen Kolkhozs at 13 Jauniela, Old Town (2019) [30]. 
RPI Campus on Kïpsala Island, Riga city. 1969-1986. It is one of the best known and largest architectural objects of D. Danneberga. She started to design it in 1969, when the Design Institute «Pilsētprojekts» («City Project») was commissioned by RPI to develop technical and economic substantiation for the construction of the entire RPI complex on Kipsala Island. The first master plan for the construction of Kipssala Campus was developed by architects Jānis Vilcinšs and Uldis Zakis. The work was then continued by architects Kārlis Alksnis and Daina Danneberga.

Initially, D. Danneberga worked on the project of RPI Campus on Kipsala Island, anticipating that more than 10000 students will study at RPI. At that time, the building of the Faculty of Radio Engineering and Communication (1968) was built, which was supplemented by the architect with three large blocks of auditoriums. The Campus was designed according to the so-called carpet-type building principle, filling the territory evenly with spatially and functionally connected faculty buildings. Students' dormitories (service hotels), student canteen for 600 people, residential buildings for teachers and a kindergarten were also planned. Two student dormitories were planned, but only one was built. In the place of the second dormitory building, the hotel «Islande» was later built. The complex also includes a swimming pool, but the construction of residential buildings for teachers and the kindergarten were not started.

2.5 million rubles were allocated for the construction of each academic building. Each building had to be constructed mainly using pre-made reinforced concrete constructions.

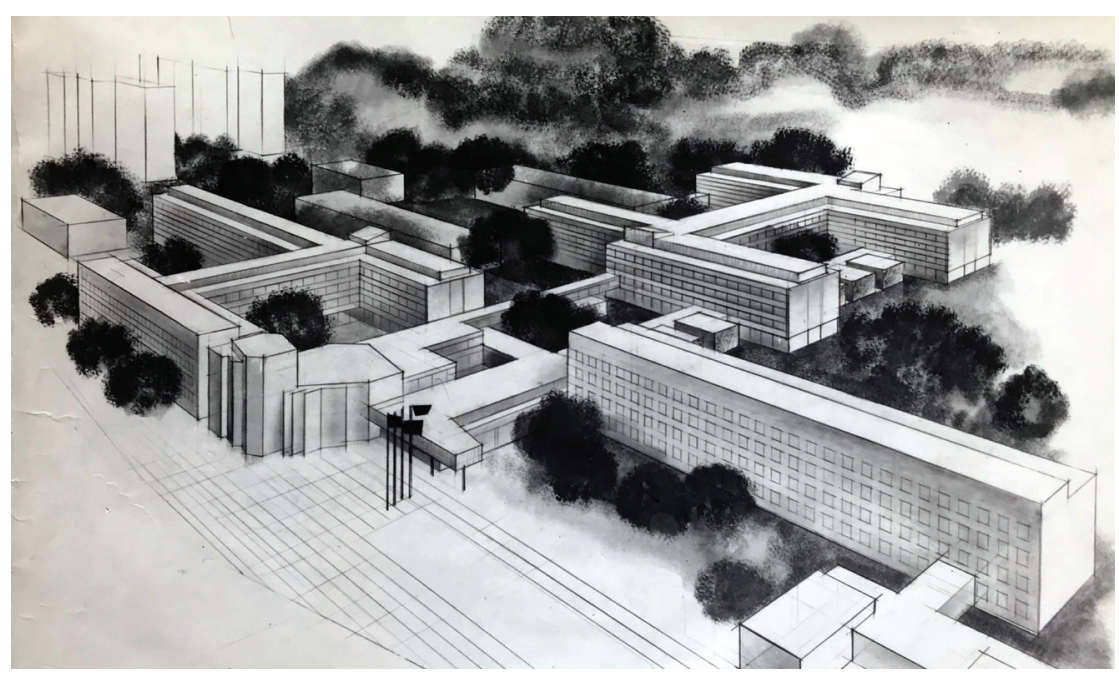

Figure 17. Sketch of the Design Institute «Pilsētprojekts» («City Project») RPI on Kīpsala Island, overview (1969) [31]. 
Figure 18. Model of RPI Student's Dormitories on Kīpsala Island by architect D. Danneberga (together with architect Baiba Maike) (1980s) [32].

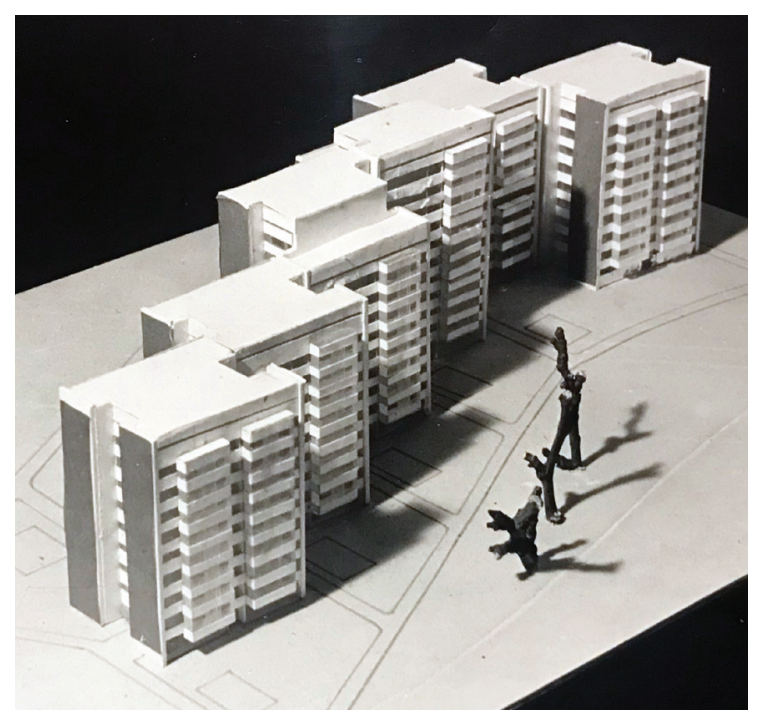

Contribution of Architect

Daina Danneberga to the Architecture in the Second Half of the 20th Century

The academic buildings according to the Soviet regulations should be no more than four storey high. The upper, fifth floor of the Faculty of the drawing room for the Department of Architecture - was designed as individual constructions. Also, the skylights used in this room were not produced in those times. A roofer was found who, to individual orders, made such windows - with double glazing and a side slope for water drainage.

The student dormitories are made as a separate architectural object. Its project was developed together with architect Baiba Maike. The architects extended the set space of $6 \mathrm{~m}^{2}$ per student $14 \mathrm{~m}^{2}$. The finishing of dormitory facades was unique. It was covered with glazed ceramic tiles made at the «Lode» factory [33].

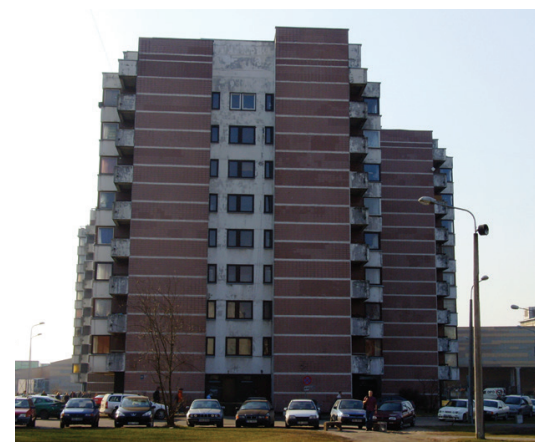

Figure 19. RPI Student's Dormitories on Kīpsala Island (2008) [34].

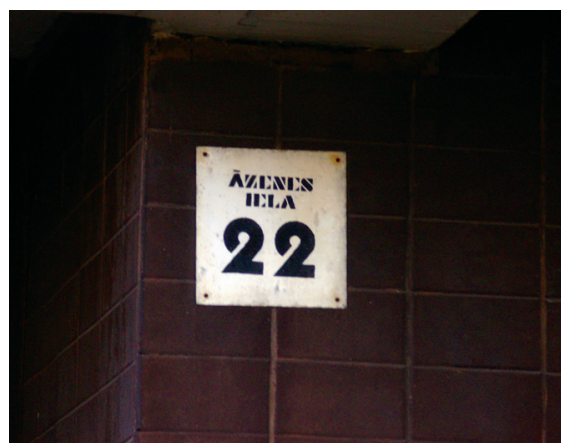

Figure 20. Glazed ceramic tiles on the facade of RPI Students' Dormitory (2008) [35]. 
Under the leadership of D. Danneberga, series of buildings of RPI Campus on Kìpsala Island were built from 1970 to 1986 (Table 1).

Table 1

Buildings designed by D. Danneberga for RPI Campus on Kīpsala Island from 1970 to 1986

\begin{tabular}{|c|c|c|}
\hline 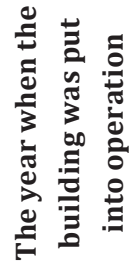 & Initial function and address & Present function and address \\
\hline$\stackrel{\circ}{\stackrel{2}{2}}$ & $\begin{array}{l}\text { Building of the Faculty of } \\
\text { Chemistry along the Zunda } \\
\text { Canal at } \\
14 \bar{A} \text { zenes iela }\end{array}$ & $\begin{array}{l}\text { Building of the Faculty of Materials } \\
\text { Science and Applied Chemistry at } \\
7 \text { Paula Valdena iela }\end{array}$ \\
\hline 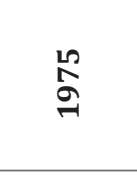 & $\begin{array}{l}\text { Building of the Faculty of Civil } \\
\text { Engineering at } \\
16 \overline{\text { Azenes iela }}\end{array}$ & $\begin{array}{l}\text { Building of the Faculty of } \\
\text { Mechanical Engineering, } \\
\text { Transport and Aeronautics at } \\
\text { 6B Kīpsalas iela }\end{array}$ \\
\hline 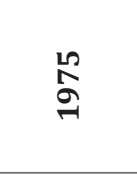 & $\begin{array}{l}\text { Student Canteen with the } \\
\text { capacity of } 600 \text { places at } \\
18 \overline{\text { Azenes iela }}\end{array}$ & $\begin{array}{l}\text { Reconstructed in } 2013 \text { for the } \\
\text { Faculty of Architecture and } \\
\text { Institute of Design Technologies at } \\
6 \text { Kipsalas iela }\end{array}$ \\
\hline$\stackrel{\infty}{\stackrel{\infty}{a}}$ & $\begin{array}{l}\text { The second building of Faculty } \\
\text { of Civil Engineering at } \\
20 \text { Āzenes iela }\end{array}$ & $\begin{array}{l}\text { Building of Faculty of Civil } \\
\text { Engineering at } 6 \text { A Kïpsalas iela } \\
\text { (currently under reconstruction) }\end{array}$ \\
\hline $\begin{array}{l}\text { : } \\
\text { హి }\end{array}$ & $\begin{array}{l}\text { The first building of students' } \\
\text { dormitories at } \\
22 \text { Āzenes iela }\end{array}$ & $\begin{array}{l}\text { Students' Dormitory at } \\
8 \text { Āzenes iela }\end{array}$ \\
\hline$\underset{\mathscr{\infty}}{\mathscr{\sigma}}$ & 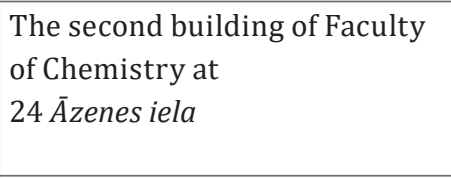 & $\begin{array}{l}\text { The second building of Faculty } \\
\text { of Materials Science and Applied } \\
\text { Chemistry at } \\
3 \text { Paula Valdena iela }\end{array}$ \\
\hline $\begin{array}{l}\text { L2 } \\
\text { O̊ } \\
\sim\end{array}$ & $\begin{array}{l}\text { Project for the warehouse } \\
\text { of chemical agents. The } \\
\text { construction was started in } \\
1988 \text { (due to a lack of financing, } \\
\text { the construction stopped } \\
\text { in 1996) }\end{array}$ & $\begin{array}{l}\text { In 1999, the warehouse was } \\
\text { reconstructed into a building for } \\
\text { RTU Scientific Library at } \\
5 \text { Paula Valdena iela }\end{array}$ \\
\hline ஜ̊ & $\begin{array}{l}\text { The second eleven-story } \\
\text { building of students' } \\
\text { dormitories at } \\
\text { 22a Āzenes iela }\end{array}$ & $\begin{array}{l}\text { Students' Dormitory at } \\
6 \overline{\text { Azenes iela }}\end{array}$ \\
\hline
\end{tabular}




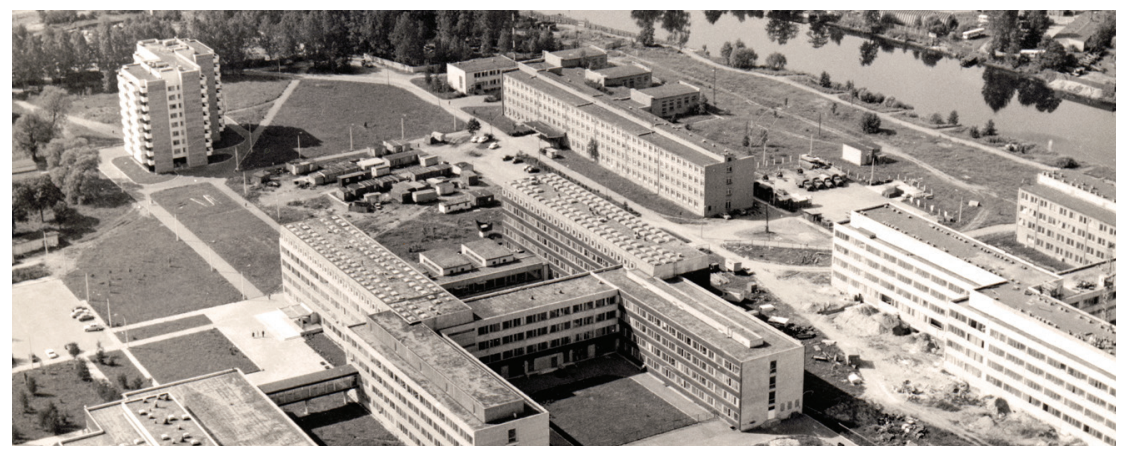

Figure 21. View to RPI Campus on Kīpsala Island (1980s) [36].

Jugla Sanatorium Forest School in Upeslejas, Stopiṇi parish. 1971-1977. In addition to designing RPI, architect D. Danneberga also created other socially important objects. One of them is the complex of Jugla Sanatorium Forest School (at present - Riga Sanatorium Elementary Boarding School).

Along the River Mazā Jugla and the pine forest, surrounded by centuries-old linden trees and oaks, where the flowers bloom early in spring and bonfires burn brightly in Midsummer Night (Summer Solstice), the construction of a new «manor» for children was starded in 1974 [37]. The school was designed for 400 pupils who need to improve and strengthen their health. The complex consists of 11 separate pavilions connected to the common central communication. On the ground floor there are classes for children of different ages, a canteen, a hall, an open-air gym, a hospital, a workshop and a laundry; but on the first and second floor a boarding house and recreation area [38]. Each enclosure has its own entrance and a cloakroom, as well as an internal courtyard where it is possible to breathe fresh air and run out in spring and autumn.

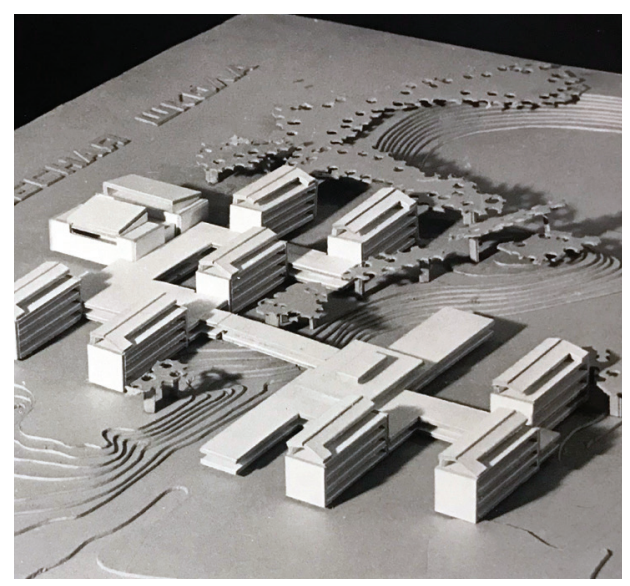

Figure 22. Model of the Jugla Sanatorium Forest School (1971) [39]. 
The pavilions are well sun lighted and ventilated. They are organically integrated into the surrounding natural environment. A strong boost in emotional expression has been achieved in a bright, spacious room, located at the junction of elementary school and secondary school classes. Free-standing fireplace - a symbolic campfire is located there [40].

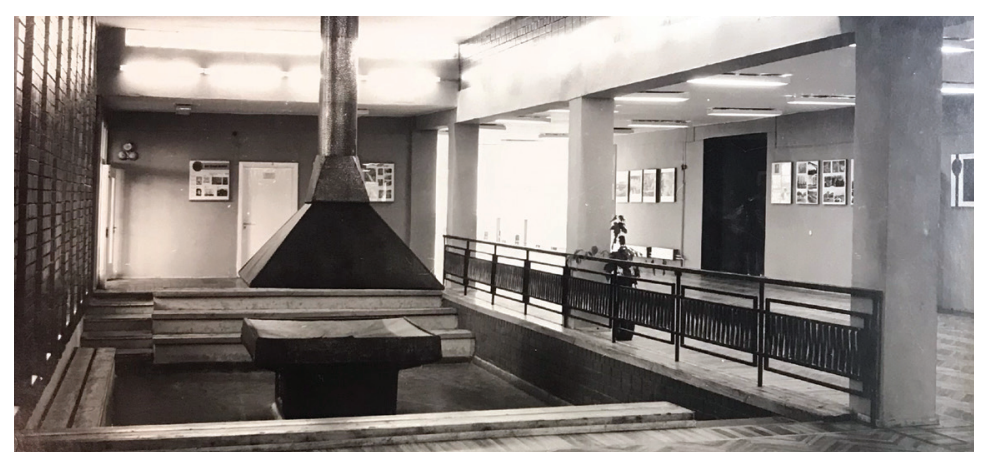

Figure 23. Free-standing fireplace of Jugla

Sanatorium Forest School (1977) [41].

The architect has convincingly demonstrated her professional maturity with the structurally justified aesthetics of the whole building and the language of logically rhythmic facades. It is a thorough, clear and thoughtful architecture [42].

Residential Building with a Kindergarten at 362 Brīvības bulvāris, Riga city. 1980. Architects D. Danneberga, A. Ārgale, A. Kokins. At a time when the construction of multi-storey residential buildings was massively implemented by standard projects, architects sometimes managed to give them individual features [43].

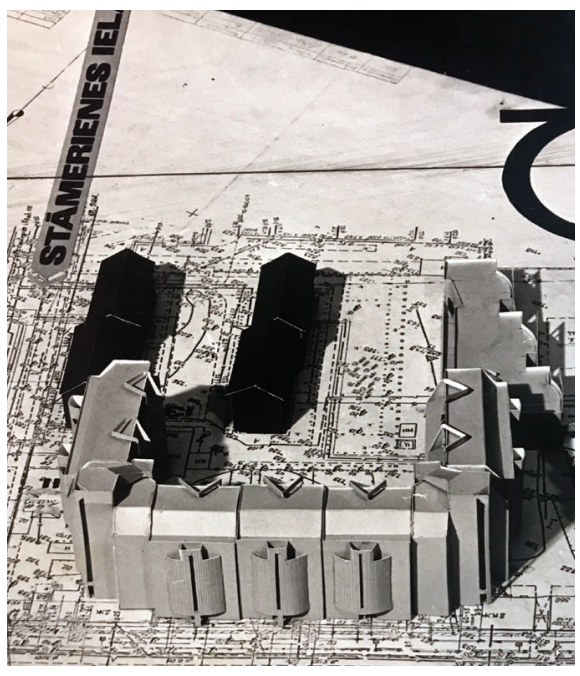

Figure 24. Model of Residential Building with a Kindergarten at Stāmerienas iela (1980) [44]. 
One example is a 70-apartment residential building at 362 Brīvības bulvāris, at the corner of Stāmerienas iela in Riga city. It was intended to emphasize the corners of the multi-storey building with towers typical for Riga's historic building and to build a kindergarten on the ground floor. Only a few sections and one tower were built. At the corner of Stāmerienas iela, another building was built later. The building designed by D. Danneberga and her colleagues continues to draw attention to the elegant facades where strong bow windows are blocked with rounded configuration of balconies.

\section{Bulduri Sovkhoz-technical School at 6 Viestura iela, Jūrmala} city. 1973-1990. Architects D. Danneberga and A. Ārgale. The building is a voluminous complex of premises for various functions with a complicated but balanced volume composition. Here, as well as in the present Riga Technical School of Tourism and Creative Industries, the principle of contrast between the tone of the finishing materials and the character of architectural forms has been successfully played. In the central part of the complex, where the study and administration rooms are located, there is a combination of cubic volumes. On the background of the yellow-brick, neutral surfaces, white building objects with sharply marked ribbon windows stand out. The wings of complex where study conservatories and auxiliary rooms are located contrast with these shapes at the same time joining them harmoniously. The peculiarly constructed building has been successfully blended with the subtle architectural landscape of Jürmala city and looks well next to the buildings of the Dimdonis Gardening Technical School built in the early 20th century that are in the foreground of the complex [45]. At present, the Bulduri Gardening Secondary School is located at the abovementioned premises. Within the school building complex, it was planned to improve the quality of life of teachers and pupils. That is why both teachers' residential buildings and student dormitories were designed. The project of dormitories remained unrealized due to changes in political and economic conditions in the 1990s.

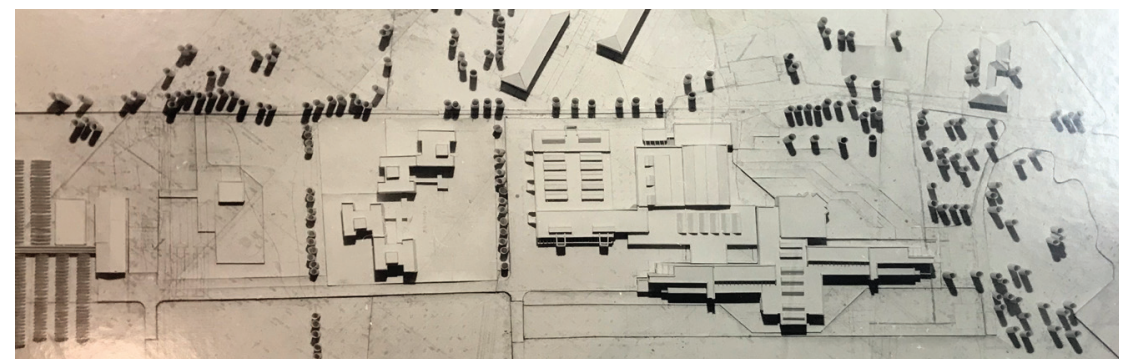

Figure 25. The model of Bulduri Sovkhoz-technical School at 6 Viestura iela in Jūrmala city (1973) [46]. 


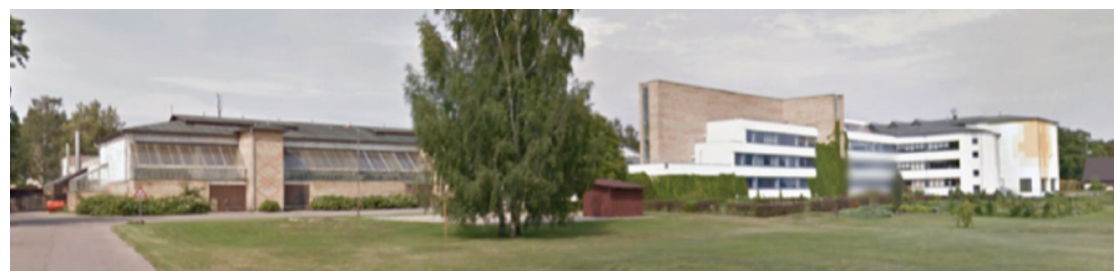

Figure 26. Bulduri Sovkhoz-technical School at 6 Viestura Street in Jūrmala city (2017) [47].

One of D. Danneberga's last objects was a residential building with a store at 231/1 Brīvības bulvāris (1985). In 1996, D. Danneberga took part in redesigning of the RTU Hotel «Laine», but in 1998 she developed a project for a residential building and garage at 5 Kanālu iela in Jürmala city.
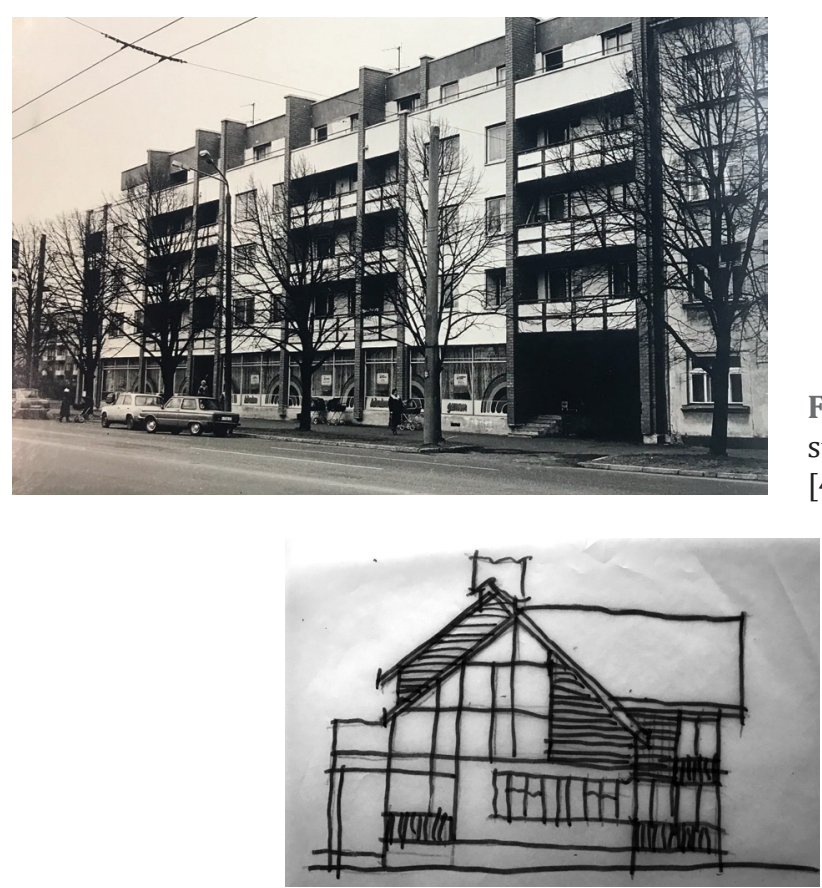

Figure 28. Sketch of D. Dannebergaresidential building with garage at 5 Kanāla iela, Jūrmala city (2015) [49].
Figure 27. Residential building with a store at 231/1 Brīvības bulvāris (1985) [48].

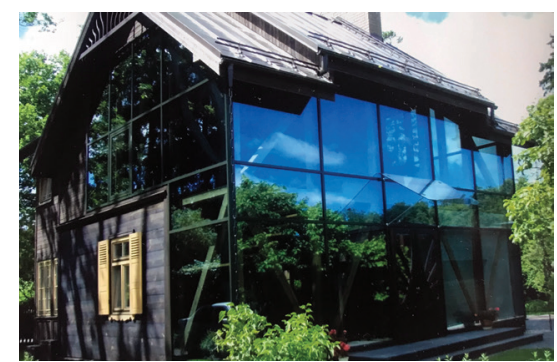

Figure 29. Residential building with garage at 5 Kanāla iela, Jūrmala city (2015) [50].

As with each architect's practice, several projects remained unrealized. In 1958, D. Danneberga and T. Dannebergs participated in the competition for the best project for the construction of low-rise individual residential buildings in towns and villages of the LSSR. The 
competition was organized by the State Committee for Construction and Architecture of the LSSR Council of Ministers, together with the Union of LSSR Architects. The aim of the competition was to obtain projects of good, economical two-storey apartment block houses with appropriate climatic and living conditions for the LSSR, developing new types of projects for the construction of cooperative and collective as well as individual residential buildings. According to the competition program, each apartment had to have its own plot of land of 400-600 $\mathrm{m}^{2} .32$ projects were submitted for the competition. D. Danneberga and T. Dannebergs received the second prize and 5000 rubles. At the evaluation of the project it was noted that it stands out with a simple building plan suitable for local conditions and a constructive solution, but the architecture and the exterior of the building are tasteful and reserved [51].

In 1959, D. Danneberga together with architect Elga Krastina participated in a competition with projects for summer houses and garden cottages for resort towns and urban green areas in LSSR, organized by the State Committee for Construction and Architecture of the LSSR Council of Ministers, the Union of LSSR Architects and the Executive Committee of the Workers' Council of Riga City. 19 projects were submitted to the competition. Both architects won the first prize and 4000 rubles [52].
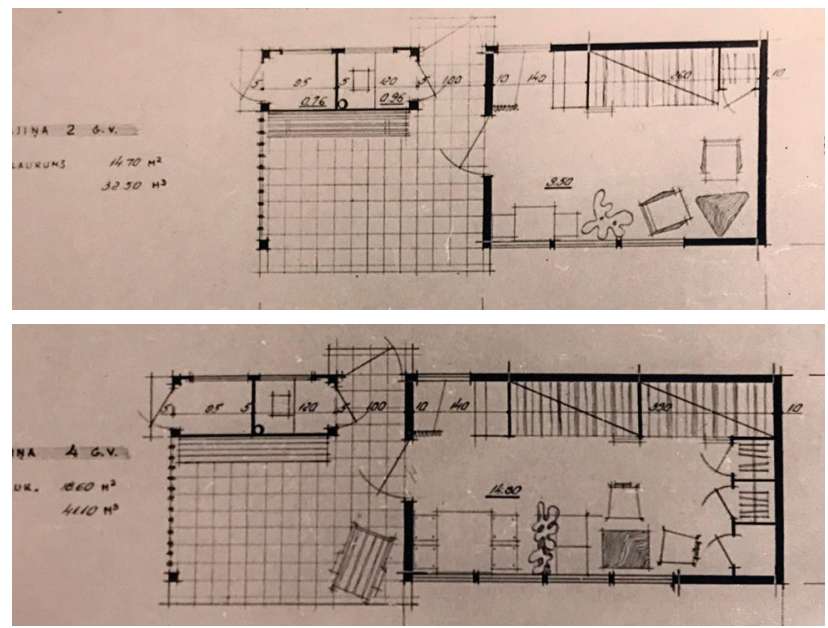

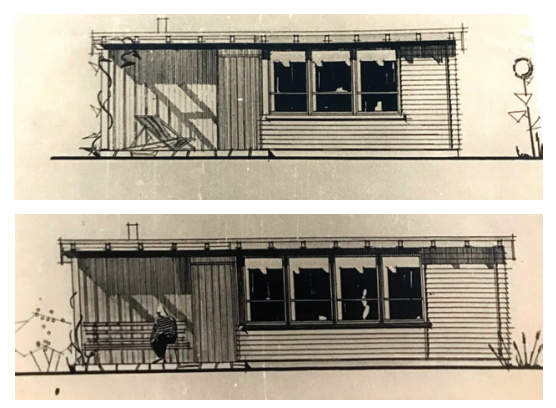

Figure 30. Project of summer houses and garden cottages by D. Danneberga and E. Krastina (1959) [53].

In 1959, D. Danneberga, P. Fogels, E. Krastina and O. Krauklis, took part in the competition of designing a project for the Daile Theatre new building in the between Sarkanarmijas (at present - Bruninieku), Lenina (at present - Brīvibas) and Šarlotes iela. Of the 25 submitted projects, the jury selected six, three of which were rewarded and three were bought. 
Among them were the project designed by D. Danneberga and her colleagues, which was awarded 4000 rubles [54].

In 1960, it was planned to build a Panoramic Cinema in Riga with 2300 seats. Architects of the National Project Building Institute O. Fogels, O. Krauklis and D. Danneberga [55] - developed a project for the new cinema.

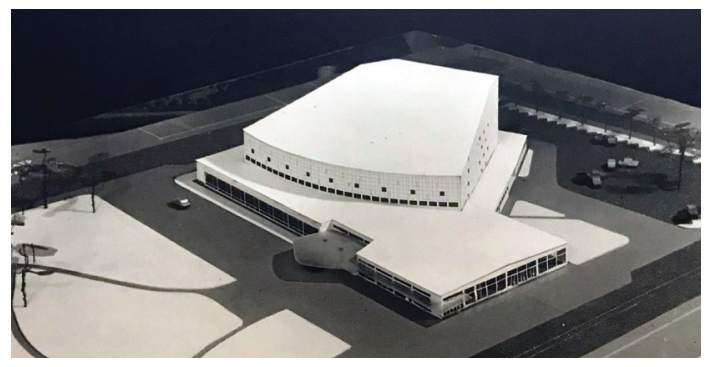

Figure 31. Model of the Riga Panoramic Cinema (1960) [56].

It was difficult to design such a cinema because the panoramic cinema is much more complex than the widescreen. The peculiarities of the panoramic cinema made it necessary to create a new type of building that radically differed from the cinemas previously known. A building plot was selected for construction, which was demarcated by K. Barona, Artilērijas, P. Stučkas (at present - Tērbatas) and Lielgabala iela. The site of the cinema building was planned in the north part of the block, leaving the southern part for a square. It was planned to have a parking space for 80 cars. The cinema project included two buildings. The predominant element was the high construction of the hall, which grows out of a group of one-storey service spaces. Lobby and buffet facilities were intended in the foyer. In the lobby, wide stairs led viewers to the hall with 2300 seats [57]. As mentioned earlier, the project of the Riga Panoramic Cinema was realized in the Tselinograd.

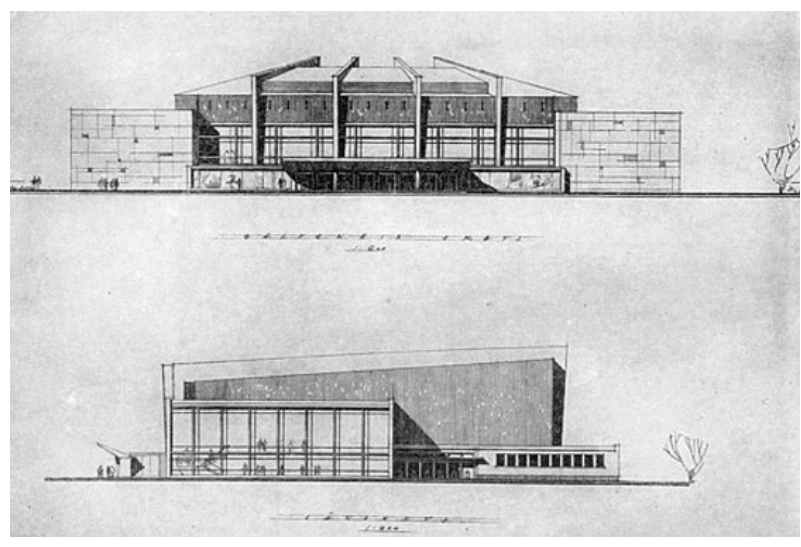

Figure 32. Project of the Riga Panoramic Cinema (1960) [58]. 
In 1967, D. Danneberga together with architect Andris Purvinš and architecture student Zigurds Lazdinšs received a split second and third prize in the design competition for the proposal for the Complex of Composers' Creative Centre in Melluži (residential area and neighbourhood of the Jūrmala city) near the sea between Peldu and Dārza iela. The building was designed on a plot of land with a flat and clear place adjacent to the dunes overgrown with pine forest [59]. The authors suggested that four groups of locked cottages were arranged around a spacious yard.

Figure 33. Project of the Complex of Composers' Creative Centre in Melluži (1967) [60].

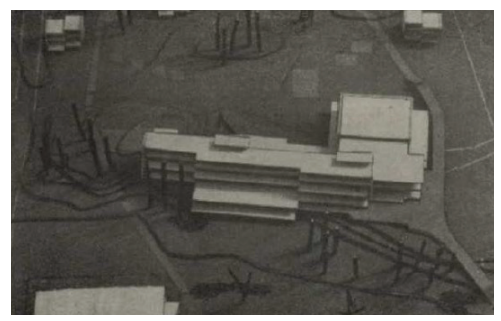

In 1978, the team of the authors of the Third Workshop of the Design Institute «Pilsētprojekts» («City Project») - architects D. Danneberga and A. Árgale - designed the Theatre Society Building in Old Riga, in the present Livvu Square, opposite the Riga Russian Theatre. The building was designed with a public area, a hall, a 75-seat theatre cafe and administrative facilities. An innovative detail was the solution of the hall one part of it was designed with progressively arranged spectator places and the other - as a space suitable for experimental performances. In the project an intimate courtyard characteristic of the Old Town, which could be used for outdoor shows, was included [61].

Figure 34. Model of the Theatre Society Building in Old Riga (1978) [62].

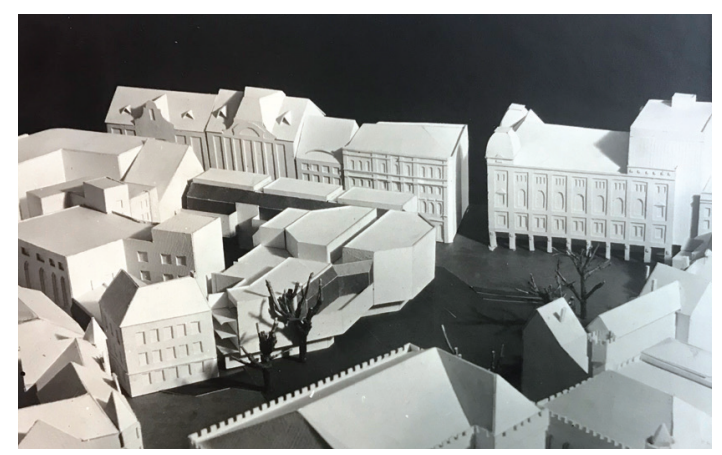

In 1983 Building Complex of the Training Centre of Personnel of the Council of Latvian Republican Trade Union at Rozes iela in Purvciems District was begun to build in Riga city by Architect D. Danneberga. The building was to be built next to the Mébel,u nams 
(Furniture House). It was intended to build the complex with 250 study rooms, an assembly hall, a hotel, a canteen and a small cafe. The complex was designed so that together with the Furniture House and other buildings it would create a closed area for car parking. It was designed as a four-storey building of reinforced concrete constructions. The building was not completed [63].

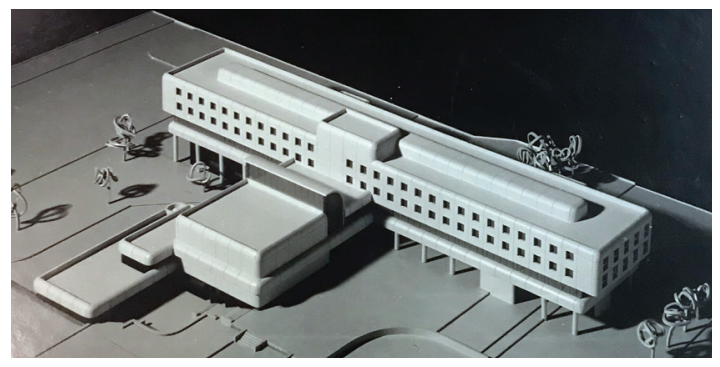

Figure 35. Model of the Building Complex of the Training Centre for Personnel of the Council of Latvian Republican Trade Union at Rozes iela in Riga (1983) [64].

In the 1980s, D. Danneberga designed several more buildings that were either not realized or not completed, for example, a Training Complex with dormitories «Intūrists» in Dubulti (administrative centre and the oldest part of Jürmala city) and the new building of the Faculty of Pedagogy of Latvian State University at 74/76 Jürmalas gatve.

\section{Conclusions}

D. Danneberga is one of the most prominent architects of public and residential buildings in Latvia. Her works are a significant contribution to the Latvian cultural environment. However, today, with no unanimous opinion on the meaning and architectural quality of Soviet-era buildings, there is a high risk of losing unique values because the buildings of that time are often brutally altered or even demolished.

Almost all works of D. Danneberga are buildings of artistic expression with high cultural and historical value. They are a typical testimonys of the highest achievement in architecture of those times, which will serve for more than just one generation.

\section{CONFLICT OF INTEREST}

The authors of the scientific article acknowledge a conflict of interest related to the joint professional work of the authors and members of the Editorial Board. The inclusion of this article in the issue was decided by those members of the Editorial Board who are not the authors of this article. 


\section{LIST OF SOURCES AND LITERATURE}

[1] Personāla dokumentu valsts arhīvs (turpmāk - PDVA) 959. f., 1. apr., 555. l., 231. lp.

[2] Foto no D. Dannebergas personīgā arhīva. No kreisās - Dainas māte Leontīne, māsa Guna un Daina dzīvoklī Rìgā (ap 1934).

[3] Foto no D. Dannebergas personīgā arhīva. Šūšanas uzṇēmuma «K. Kimelis» logo (1940).

[4] Foto no D. Dannebergas personīgā arhīva. Dannebergi nedēḷu pēc kāzām Mellužos (1949).

[5] Foto no D. Dannebergas personīgā arhīva. I. Veigners un D. Danneberga kāzu dienā (1960).

[6] Foto no D. Dannebergas personīgā arhīva. Daina Danneberga ar meitām Helgu un Noru (ap 1980).

[7] PDVA 959. f., 1. apr., 555. 1., 233. lp.

[8] Latvijas Universitātes (turpmāk - LU) arhīvs 49135. f., 6. lp.

[9] LU arhīvs 49135 f., 17. lp.

[10] LU arhīvs 49135 f., 29. lp.

[11] Eniņa, A., Krastiņš, J. Creative Work of the Architect Daina Danneberga in the Context of Architectural Heritage of the Soviet Period (Arhitektes Dainas Dannebergas daiḷrade padomju laika arhitektūras mantojuma kontekstā). Scientific Journal of Riga Technical University. Architecture and Urban Planning. Vol 4, 2010, p. 128.

[12] PDVA 959. f., 1. apr., 555. 1., 229. lp.

[13] Treija, S., Holcmane, V. Daina Danneberga. Latvijas Architektūra, 2014/2015 Decembris/Janvāris, Nr. 116, 104.-106. lpp.

[14] Jorēns, E. Pie Rīgas ziemel̦austrumu robežas. Rīgas Balss, 1963. gada 20. februāris, Nr. 43, 5. lpp.

[15] Tīlmanis, O. Arhitektūra, māksla un celtniecība. Māksla, 1960. gada 1. aprīlis, Nr. 2, 18. lpp.

[16] Jorēns, Ē. Par četriem arhitektiem un tukšo klajumu Juglā. Rīgas Balss, 1959. gada 26. augusts, Nr. 201, 3. lpp.

[17] Apsītis, V. Kopīgiem Spēkiem. Literatūra un Māksla, 1958. gada 29. novembris, Nr. 48, 1. lpp.

[18] Latvijas Arhitektūras muzejs (turpmāk - LAM) D21-5.

[19] Apkaimju vēsture: kā tika apbūvēta Rīga? [tiešsaiste]. https://www. riga.lv/lv/news/apkaimju-vesture-ka-tika-apbuveta-riga?9625 [skatīts: 17.01.2018].

[20] Krauklis, O. Rīga Cel̦inogradai. Māksla, 1964. gada 1. aprīlis, Nr. 2, 18. lpp.

[21] Rīdzinieki uzcēluši kultūras pili jauno zemju apguvējiem. Dzimtenes Balss, 1964. gada 13. septembris, Nr. 74, 1. lpp.

[22] Krauklis, O. Rīga Cel̦inogradai. Māksla, 1964. gada 1. aprīlis, Nr. 2, 16. lpp.

[23] Дворец Целинников в Астане [online]. http://silkadv.com/ru/node/719 [cited: 15.01.2019].

[24] Конгресс-холл в Астане [online]. https://tonkosti.ru/\%D0\%9A\%D0\%BE $\% D 0 \% B D \% D 0 \% B 3 \% D 1 \% 80 \% D 0 \% B 5 \% D 1 \% 81 \% D 1 \% 81-\% D 1 \% 85 \% D 0 \% B E$ \%D0\%BB\%D0\%BB_\%D0\%B2_\%D0\%90\%D1\%81\%D1\%82\%D0\%B0\%D0\%B $D \% D O \% B 5$ [cited: 20.01.2018]. 
[25] LAM 6320/D21.

[26] LAM 6320/D21.

[27] Krastiṇš, J. Doma laukums. Mācību stunda Rīgas arhitektūrā. Diena, 1993. gada 31. jūlijs, Nr. 156, 12.-13. lpp.

[28] Gegere, A. 150 arhitektūras pieminekḷi. Rìgas Balss, 1975. gada 28. aprīlis, Nr. 99, 6. lpp.

[29] LAM D21-23.

[30] Foto I. Gudro. Latvijas Zvejnieku kolhozu savienības nams Jaunielā 13, Vecrīgā (2019).

[31] Rīgas Tehniskās universitātes (turpmāk - RTU) Inženierzinātṇu vēstures pētniecības centra (turpmāk - IVPC) Vēstures muzejs (turpmāk - VM).

[32] LAM D21-8.

[33] Bērziṇa, V. Eksperimentāla paneḷu apdare. Cīna, 1977. gada 14. jūlijs, Nr. 162, 2. lpp.

[34] Foto I. Gudro. Skats uz RPI Ķīpsalas studentu kopmītnēm (2008).

[35] Foto I. Gudro. Glazētās keramikas plāksnītes uz RPI Ķīpsalas studentu kopmītņu fasādēm (2008).

[36] RTU IVPC VM.

[37] Ernštreite, V. Priežu sila ielokā. Zvaigzne, 1978. gada 15. maijs, Nr. 10, 4.-5. lpp.

[38] Jaunas skolas. Austrālijas Latvietis, 1977. gada 5. augusts, Nr. 1389, 7. lpp.

[39] LAM D21-7.

[40] Eniña, A., Krastinšs, J. Creative Work of the Architect Daina Danneberga in the Context of Architectural Heritage of the Soviet Period (Arhitektes Dainas Dannebergas daiḷrade padomju laika arhitektūras mantojuma kontekstā). Scientific Journal of Riga Technical University. Architecture and Urban Planning. Vol. 4, 2010, p. 129.

[41] LAM 6321/D21.

[42] Enin,a, A., Krastinsš, J. Creative Work of the Architect Daina Danneberga in the Context of Architectural Heritage of the Soviet Period (Arhitektes Dainas Dannebergas daiḷrade padomju laika arhitektūras mantojuma kontekstā). Scientific Journal of Riga Technical University. Architecture and Urban Planning. Vol. 4, 2010, p. 41.

[43] Dripe, J. Ko turpmāk darīsim, kā tālāk iesim? Māksla, 1987. gada 1. marts, Nr. 5, 11.-13. lpp.

[44] LAM 6316-D21.

[45] Eniña, A., Krastiṇš, J. Creative Work of the Architect Daina Danneberga in the Context of Architectural Heritage of the Soviet Period (Arhitektes Dainas Dannebergas daiḷrade padomju laika arhitektūras mantojuma kontekstā). Scientific Journal of Riga Technical University. Architecture and Urban Planning. Vol. 4, 2010, p. 130.

[46] LAM 6314/D21.

[47] Foto no Google Maps.

[48] LAM 6323-D21.

[49] D. Dannebergas skice - dzīvojamās ēka ar garāžu Kanāla ielā 5, Jūrmalā (2015). 
[50] Foto no D. Dannebergas personīgā arhīva. Dzīvojamā ēka ar garāžu Kanāla ielā 5, Jūrmalā (2015).

[51] Rindu un bloksēta dzīvojamo ēku projektu konkursa rezultāti. Literatūra un Māksla, 1958. gada 5. jūlijs, Nr. 27, 1. lpp.

[52] Prēmēti tikai dārza mājiṇu projekti. Literatūra un Māksla, 1959. gada 29. augusts, Nr. 35, 4. lpp.

[53] LAM Daina Danneberga D21-2.

[54] Holcmanis, A. Kāda būs Dailes teātra jauna ēka. Literatūra un Māksla, 1959. gada 12. decembris, Nr. 50, 3. lpp.

[55] Tīlmanis, O. Arhitektūra māksla un celtniecība. Māksla, 1960. gada 1. aprīlis, Nr. 2, 19. lpp.

[56] LAM D21-6.

[57] Danneberga, D. Rīgas panorāmas kinoteātrī būs 2300 vietas. Rìgas Balss, 1960. gada 5. aprīlis, Nr. 81, 5. lpp.

[58] Перевощиков, Ю. Дворец спорта [online]. http://riga.zurbu.net/tag:\%D0 \%9D\%D0\%B5\%D1\%80\%D0\%B5\%D0\%B0\%D0\%BB\%D0\%B8\%D0\%B7\%D0 $\% B E \% D 0 \% B 2 \% D 0 \% B 0 \% D 0 \% B D \% D 0 \% B D \% D 0 \% B E \% D 0 \% B 5 / f e e d$ [cited: 05.02.2019].

[59] Skalbergs, J. Komponistu jaunrades nama projektu konkurss. Literatūra un māksla, 1967. gada 6. maijs, Nr. 18, 8. lpp.

[60] Holcmanis, A. Jaunrades laboratorijas. Māksla, 1967. gada 1. aprīlis, Nr. 2, 18. lpp.

[61] Bērzinna, V. Pilsētas rītdienai. Cīna, 1978 gada 15. jūlijs, Nr. 162, 3. lpp.

[62] Foto no D. Dannebergas personīgā arhīva. Teātra biedrības ēkas makets Vecrīgā.

[63] Danneberga, D. Jauns vaibsts Purvciema sejā. Rìgas Balss, 1984. gada 15.novembris, Nr. 259, 3. lpp.

[64] LAM 6319-D21.

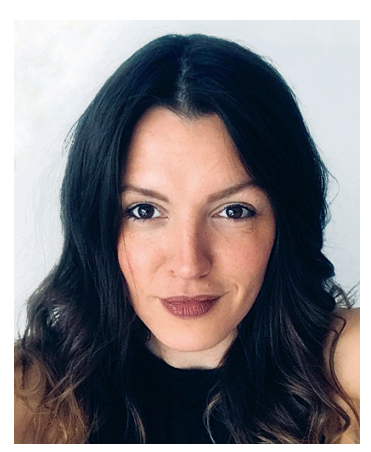

ILZE GUDRO, Dr. sc. ing., is currently Head of the Research Centre for Engineering History of Riga Technical University and a lecturer with the Institute of Design Technologies of RTU. Her main academic interests include the history of Riga Technical University, engineering sciences, interior, furniture and product design, materials science. She is a member of the team organizing the exhibitions of works of bachelor and master students of the Institute of Design Technologies of RTU (e. g. Fashion show «Kīpsalas Pavasaris», design product exhibitions «Kīpsalas Dizaina Kods», «Design Isle», etc.).

Address: 1 Kronvalda bulvāris, Room 203, Riga, LV-1010, Latvia

Phone: +37128897223

E-mail: ilze.gudro@rtu.lv 


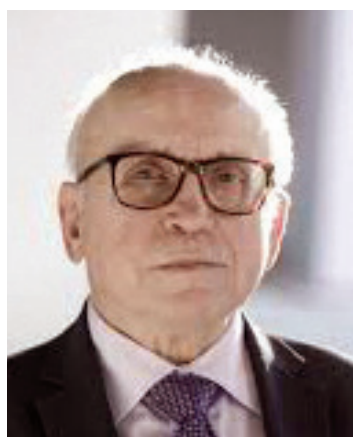

JĀNIS KRASTIN̦Š, Dr. habil. arch. (1991), is full member of the Latvian Academy of Sciences (1994, holder of the Great Medal 1998), Professor of RTU and a member of the Latvian Association of Architects (1970). He has designed numerous public and residential buildings and carried out investigations of historic structures. He is the author of more than 690 scientific works published in Europe and the USA, including 28 books on various aspects of history and theory of architecture.

Address: 6 Kīpsalas iela, Room 412, Riga, LV-1048, Latvia

E-mail: janis.krastins_1@rtu.lv

Ilze Gudro, Jānis Krastiņ̌̌

\section{Arhitektes Dainas Dannebergas devums arhitektūrā 20. gadsimta otrajā pusē}

Rakstā atspoguḷots ievērojamās latviešu arhitektes Dainas Dannebergas devums Latvijas arhitektūrā, kā arī dzīves nozīmīgie notikumi un izaugsme. Dzīvojot un strādājot padomju varas gados, arhitekte projektējusi gan dzīvojamās, gan sabiedriskās ēkas, kas joprojām tiek izmantotas un kuru kultūrvēsturiskās nozīmes līmenis laika gaitā ir noteikti audzis. Atpazīstamākais arhitektes projektētais objekts ir RPI / RTU, studentu pilsētina Ķīpsalā. Pie tās projektēšanas D. Danneberga strādāja no 1969. līdz 1986. gadam. Arhitekte izstrādājusi arī vairāku citu mācību iestāžu, kā arī sabiedrisko un dzīvojamo ēku projektus, kas realizēti gan Latvijā, gan ārpus tās.

Atslēgas vārdi: Daina Danneberga, RPI / RTU studentu pilsētiṇa Ķ̄ipsalā, 20. gadsimta otrās puses arhitektūra.

Илзе Гудро, Янис Крастиньш

\section{Вклад архитектора Дайны Даннеберги в архитектуру второй половины XX века}

Статья отражает вклад выдающегося латвийского архитектора Дайны Даннеберги в латвийскую архитектуру, а также значимые события и факты ее жизни. Живя и работая в советское время, архитектор проектировала как жилые, так и общественные здания, которые все еще используются, и уровень их культурно-исторического значения, несомненно, со временем возрос. Наиболее узнаваемым объектом, проектируемым архитектором, является студенческий городок РПИ / РТУ на Кипсале, над которым Д. Даннеберга работала с 1969 года по 1986 год. Архитектор также разработала проекты для многих других учебных заведений, а также общественных и жилых зданий, как в Латвии, так и за рубежом.

Ключевые слова: Дайна Даннеберга, студенческий городок РПИ / РТУ на Кипсале, архитектура второй половины XX века. 